\title{
PEMODELAN GEOSTATISTIK 3D PADA SEBARAN BATUAN KARBONAT MENGGUNAKAN METODE KRIGING BERDASARKAN DATA RESISTIVITAS 2D DAN N-SPT
}

\author{
Fahrenzy Yona Aisha, Dwa Desa Warnana, Nita Ariyanti
}

Departemen Teknik Geofisika, Fakultas Teknik Sipil Lingkungan dan Kebumian, Institut Teknologi Sepuluh Nopember

e-mail: dwa_desa@geofisika.its.ac.id

\begin{abstract}
Abstrak. Metode Geofisika memainkan peran yang penting dalam bidang ilmu kebumian, terutama dalam menentukan struktur bumi. Dalam dunia eksplorasi, metode geofisika digunakan untuk mengestimasi sebaran sifat fisika material penyusun bumi tidak terkecuali metode geolistrik. Umumnya, metode geolistrik dilakukan untuk mengestimasi struktur bumi dalam 1D dan 2D. Seiring berjalannya waktu, kebutuhan terhadap data keadaan bawah permukaan yang lebih terkarakterisasi dengan detail dan menerus semakin meningkat. Sementara, harga yang tinggi saat melakukan akuisisi geolistrik 3D terkadang menjadi kendala dalam eksplorasi. Oleh sebab itu, diperlukan hasil penampang yang mendekati kondisi riil-nya yakni pemodelan dalam bentuk 3D berdasarkan data 2D. Untuk dapat memprediksi pola sebaran data di antara titik ukur atau antara penampang, diperlukan aplikasi metode geostatistik. Metode Geostatistik yang digunakan adalah kriging. Data kemudian dilakukan interpretasi secara kualitatif dengan mengintegrasikan dengan kondisi geologinya. Tujuan penelitian ini adalah untuk mengetahui pseudo 3D resis yang dapat menggambarkan bawah permukaan secara 3D dari data 2D. Kombinasi antara hasil dari survei geofisika dan geologi ini dapat menghasilkan persebaran distribusi karbonat di daerah penelitian yakni Kabupaten Tuban, Kec. Jenu. Kemudian, berdasarkan model persebaran karbonat mengindikasikan bahwa lingkungan penelitian ini memiliki jenis karbonat reefal dengan kombinasi batuan gamping dan dolomit.
\end{abstract}

Kata Kunci: Geostatistika; Resistivitas 2D; Pseudo 3D.

\begin{abstract}
Geophysical methods play an important role in the field of earth science, especially in determining the structure of the earth. In the world of exploration, geophysical methods are used to estimate the distribution of the physical properties of the constituent materials of the earth, including the geoelectric method. Generally, the geoelectric method is carried out to estimate the structure of the earth in $1 D$ and 2D. Over time, the need for data on subsurface conditions that are more detailed and continuously characterized increases. Meanwhile, high prices when conducting 3D geoelectric acquisitions sometimes become obstacles in exploration. Therefore, a cross section is needed that approaches its real condition, namely modeling in 3D based on 2D data. To be able to predict the pattern of data distribution between measuring points or between cross sections, the application of a geostatistical method is required. The Geostatistical method used is kriging. Data is then interpreted qualitatively by integrating with the geological conditions. The purpose of this research is to find out the pseudo 3D resis that can describe the subsurface in $3 D$ from 2D data. The combination of the results of the geophysical and geological surveys can produce a distribution of the carbonate distribution in the study area, namely Tuban Regency, Kec. Jenu. Then, based on the carbonate distribution model, it indicates that the research environment has reefal carbonate with a combination of limestone and dolomite.
\end{abstract}

Keywords: Geostatistics; 2D Resistivity; Pseudo 3D.

\section{PENDAHULUAN}

Metode geolistrik resistivitas merupakan metode geolistrik yang mempelajari sifat resistivitas (tahanan jenis) listrik dari lapisan batuan di dalam bumi. Metode ini termasuk metode yang tidak alami (aktif), sebab dalam metode ini dibutuhkan injeksi arus listrik ke dalam bumi melalui dua buah elektroda arus dan dilakukan pengukuran beda potensial melalui dua buah elektroda potensial, namun hasil dari metode ini hanyalah penampang $2 \mathrm{D}$ (Ward, 1990). Seiring berjalannya waktu kebutuhan akan analisa model bawah permukaan semakin kompleks dan semakin detail sehingga sering sekali dibutuhkan pemodelan bawah 
permukaan secara 3 dimensi. Karena analisa geologi, merupakan suatu analisa yang didasarkan pada observasi serta geoteknik dan geofisika yang hanya dilakukan pada area tertentu saja, tentunya data ini pun tidak dapat dilakukan di setiap titik pada area penelitian. Sehingga diperlukannya penghubung antar titik-titik sampel data suatu survei yakni menggunakan geostatistika (Guo dkk., 2014).

Kabupaten Tuban merupakan salah satu Kabupaten yang berada dipesisir pantai utara Pulau Jawa. Sebagai daerah yang berada dalam cekungan Jawa Timur bagian utara dan dimungkinkan sebagai wilayah potensial terdapatnya berbagai sumberdaya mineral. Sementara itu, lajur pada daerah Tuban ini pada umumnya merupakan endapan paparan yang kaya akan batuan karbonat dan jarang dijumpai endapan piroklastik. Lipatan dan sesar dapat diamati pada batuan Oligo-Miosen sampai Pliosen. Sejarah geologi daerah pemetaan diperkirakan mulai pada kala Oligo-Miosen dimana pada kala tersebut daerah ini merupakan suatu cekungan. Kemudian formasi Kujung diendapkan yang kaya akan batuan karbonat dengan lingkungan pengendapan laut dangkal sampai dalam (Hartono dan Suharsono, 1997). Dengan berbagai kejadian geologi seperti diatas maka daerah tuban menjadi daerah yang menarik untuk dlakukan penelitian distribusi karbonat sehingga dapat dilakukan rekonstruksi kejadian geologi pada daerah Kabupaten Tuban, khususnya Kecamatan Jenu.

Sehingga berangkat dari 2 permasalahan tersebut dilakukan penelitian ini dengan harapan dapat memodelkan persebaran resistivitas 3 dimensi dengan menggunakan data resistivitas 2 dimensi dan dapat menganalisa persebaran karbonat pada daerah Tuban kecamatan Jenu dengan menggunakan dara persebaran resistivitas 3 dimensi,data N-SPT dan geologi regional.

\section{Tinjauan Geologi}

Kabupaten Tuban merupakan salah satu Kabupaten yang berada dipesisir pantai utara Pulau Jawa, tepatnya di Jawa Timur, berbatasan langsung dengan Kabupaten Lamongan, di sebelah timur, Kabupaten Bojonegoro, di sebelah selatan dan Kabupaten Blora dan Kabupaten Rembang, Jawa Tengah, di sebelah Barat. Sebagai daerah yang berada dalam cekungan Jawa Timur bagian utara dan dimungkinkan sebagai wilayah potensial terdapatnya berbagai sumberdaya mineral (Al Majid dan Muljo, 2017).
Secara geografis daerah Tuban terletak pada $111^{\circ} 30^{\prime}-112^{\circ} 35^{\prime}$ BT $6^{\circ} 40^{\prime}-7^{\circ} 18^{\prime}$ LS memiliki luas

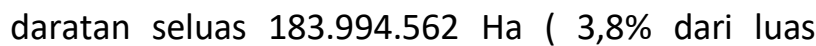
Wilayah Profinsi Jawa Timur). Adapun kondisi geologi Tuban jika ditinjau dari komposisi tanahnya ialah: Mediteran merah kuning, berasal dari endapan batu kapur di daerah bukit sampai gunung ( 38\% ) dari luas wilayah, terdapat di Kecamatan Semanding, Montong , Kerek, Palang, Jenu, sebagian Tambakboyo, Widang, Plumpang dan Merakurak; Alluvial, berasal dari endapan didaerah daratan dan cekungan ( $34 \%$ dari luas wilayah, terdapat di Kecamatan Tambakboyo, Bancar, Tuban, Palang, Rengel, Soko, Parengan, singgahan, Senori dan Bangilan; Grumusol, Berasal dari endapan batuan di daerah yang bergelombang ( $5 \%$ dari luas wilayah) terdapat dikecamatan Bancar, jatirogo, dan Senori. Sejarah geologi daerah pemetaan diperkirakan mulai pada kala Oligo-Miosen dimana pada kala tersebut daerah ini merupakan suatu cekungan. Kemudian formasi Kujung diendapkan yang kaya akan batuan karbonat dengan lingkungan pengendapan laut dangkal sampai dalam. Pada kala Miosen Tengah mulai terjadi fase regresi yang disebabkan aktifitas tektonik intra-Miosen, didaerah ini berkaitan dengan pengendapan batupasir kuarsa anggota Ngrayong formasi Tuban dengan lingkungan pengendapan litoral atau dekat pantai. Kemudian suatu fase transgresi terjadi lagi pada kala Pliosen dimana diendapkan formasi Paciran yang terletak tak selaras diatas formasi Tuban. Formasi ini tersebar cukup luas dan didominasi oleh batugamping dengan lingkungan laut dangkal. Pada kala Plistosen terjadi fase regresi yang disebabkan orogenesa PlioPlistosen. Formasi Kabuh diendapkan yang terdiri dari batupasir vulkanik dan konglomerat yang berlingkungan darat dan terletak tidak selaras di atas formasi Paciran (Hartono dan Suharsono, 1997).

\section{Stratigrafi Regional Tuban}

Daerah penelitian terletak pada salah satu kecamatan di Kabupaten Tuban yakni Jenu. Lintasan akuisisi terletak pada formasi paciran (Tpp) dengan jumlah yang banyak, sementara sisanya terletak pada dormasi alluvial (Qa) (Gambar 1). Namun, untuk mengetaui secara umum daerah penelitian maka berikut terdapat susunan stratigrafi dan juga 
batuan penyusun daerah Tuban.Stratigrafi regional lembar Tuban disusun oleh satuan endapan permukaan dan satuan batuan sedimen. Berikut pemerian satuan batuan penyusun lembar Tuban yang diurutkan dari muda ke tua dan dapat dilihat pada gambar 1.

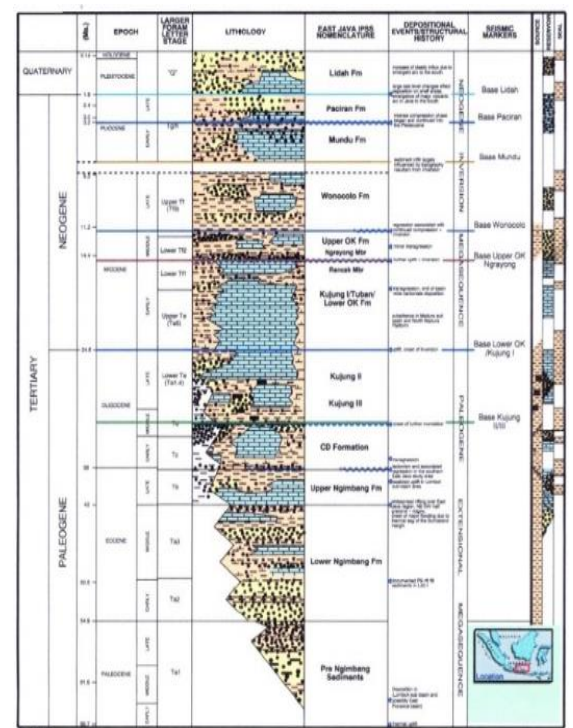

Gambar 1 Stratigrafi cekungan utara jawa (Rutley, 2001)

\section{METODE GEOLISTRIK}

Pada prinsipnya metode geofisika digunakan untuk mengetahui perubahan resistivitas lapisan batuan di bawah permukaan tanah dengan cara mengalirkan arus listrik DC (Direct Current) yang dialirkan ke bawah permukaan tanah melalui dua elektroda arus. Kemudian beda potensial yang terjadi diukur melalui dua elektroda potensial (Reynold, 1997). Setelah besar arus dan besar potensial yang dihasilkan terukur, maka resistivitas bawah permukaan dapat dihitung. Untuk mengetahui persamaan umum untuk mencari nilai resistivitas perlu diketahui hubungan antara rapat arus dan intensitas medan listrik berdasarkan Hukum OHM.

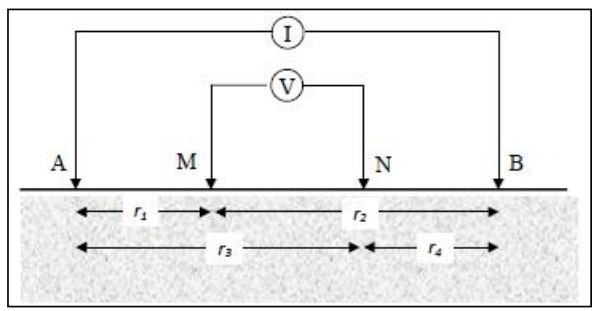

Gambar 2. Dua pasang elektroda arus dan elektroda potensial pada permukaan medium homogen isotropis dengan resistivitas $\rho$ (Telford, 1990)
Sementara itu, apabila terdapat dua elektroda arus $\mathrm{C}_{1}$ yang terletak pada permukaan suatu medium homogen, terangkai dengan elektroda arus $C_{2}$ dan diantaranya ada dua elektroda potensial $P_{1}$ dan $P_{2}$ yang dibuat dengan jarak tertentu seperti pada (gambar 2), maka potensial yang berada di dekat titik elektroda tersebut bisa dipengaruhi oleh kedua elektroda arus. Susunan keempat elektroda tersebut merupakan susunan elektroda yang biasanya dalam metode geolistrik resistivitas. Pada konfigurasi ini garis-garis aliran arus dan ekipotensial diubah oleh dekatnya kedua elektroda arus. Perubahan dari garis-garis ekipotensial yang melingkar lebih jelas pada daerah antara dua elektroda arus sebagaimana ditunjukkan pada gambar 2.

Metode geolistrik resistivitas didasarkan pada anggapan bahwa bumi mempunyai sifat homogen isotropis. Dengan asumsi ini, resistivitas yang terukur merupakan resistivitas yang sebenarnya dan tidak tergantung pada spasi elektroda. Namun pada kenyataannya bumi tersusun atas lapisan-lapisan dengan resistivitas yang berbeda-beda, sehingga potensial yang terukur merupakan pengaruh dari lapisan-lapisan tersebut. Karenanya harga resistivitas yang terukur seolah-olah merupakan nilai resistivitas untuk satu lapisan saja. Dengan demikian tahanan jenis yang terukur bukan merupakan harga tahanan jenis untuk satu lapisan saja terutama untuk spasi elektroda yang besar. Dalam hal ini yang terukur adalah tahanan jenis semu (apparent resistivity, pa).

\section{METODE GEOSTATISTIK}

Metode geostatistik pada umumnya digunakan untuk menganalisa karakteristik cebakan mineral yang biasanya menggunakan dua cara yakni statistik klasik dan statistik spasial. Dengan menggunakan dasar teori statistik spasial, ilmu geostatistik berkembang tidak hanya diaplikasikan untuk endapan cebakan mineral atau pertambangan saja. Untuk mengetahui sejauh mana hubungan spasial antara titik-titik suatu nilai, maka harus diketahui fungsi struktural yang dicerminkan oleh model semi variogramnya. Dengan menetapkan model semivariogramnya merupakan langkah awal dalam perhitungan geostatistik, disusul dengan perhitungan beberapa macam varian dan perhitungan lainnya yang akan dijelaskan dibawah ini (Wibowo, 2009). 


\section{Varian}

Sebelum menginjak ke perhitungan varian, perlu diketahui tentang perhitungan untuk hubungan antara dua gugus data. Teknik tersebut adalah kovarian dimana $X_{i}$ adalah nilai variabel yang dianggap sebagai $X, Y_{i}$ nilai variabel yang dianggap sebagai $Y, X_{\text {avg }}$ dan $Y_{\text {avg }}$ adalan nilai rata-rata dari variabel $X$ dan $Y$ degan persamaan umum sebagai berikut:

$$
\begin{aligned}
& \text { Covariance } \\
& =\frac{\sum\left(X_{i}-X_{\text {avg }}\right)-\left(Y_{i}-Y_{\text {avg }}\right)}{n-1}
\end{aligned}
$$

Sementara itu, varian merupakan ukuran seberapa jauh sebuah kumpulan bilangan tersebar. Varian disebut juga sebagai simpangan baku. Nilai varian nol mengindikasikan bahwa semua nilai sama, nilai varian rendah mengindikasikan bahwa data sangat dekat dengan nilai rata-rata, dan varian tinggi mengindikasikan nilai tersebar di sekitar nilai ratarata dan dari data satu dengan data lainnya.

Jika suatu fungsi $X$ mempunyai rata-rata $\mu=$ $E[X]$, varian dari $X(\operatorname{Var}(\mathrm{X}))$ dapta dihitung dengan persamaan berikut:

$\operatorname{Var}(X)=E\left[(X-\mu)^{2}\right]$

Jika fungsi $X$ berasal dari data kontinu dengan probability density function $f(x)$, maka:

$\operatorname{Var}(X)=\int(X-\mu)^{2} f(x) d x$

Dengan $\mu$ dicari menggunakan persamaan sebagai berikut :

$\mu=\int x f(x) d x$

Jika fungsi berasal dari data diskrit dengan probability mass function $\left(X_{1} \mapsto p_{1} \ldots \ldots, X_{n} \mapsto p_{n}\right.$, maka :

$\operatorname{Var}(X)=\sum_{i=1}^{n} p_{i}\left(X_{i}-\mu\right)^{2}$

Dan $\mu$ dicari menggunakan persamaan :

$\mu=\sum_{i=1}^{n}\left(p_{i}-X_{i}\right)$

\section{Variogram}

Analisis variogram merupakan satu tahapan dalam geostatistik yang mendeskripsikan variasi dalam sebuah parameter sebagai sebuah fungsi jarak pisah. Analisa ini didasarkan pada suatu prinsip bahwa dua titik yang berdekatan akan lebih memiliki kemungkinan untuk mempunyai nilai parameter yang mirip dibandingkan dengan dua titik yang berjauhan. Secara umum, ada dua aspek penting dalam variogram, yaitu:

- Seberapa mirip dua nilai antara dua titik yang berdekatan

- Seberapa jauh jarak dua titik sebelum mereka

\section{a) Variogram eksperimental}

Variogram eksperimental adalah variogram yang dihitung berdasarkan data yang ada. Hal ini dilakukan dengan menggunakan persamaan di bawah ini:

$\left.\gamma(h)=\frac{1}{2 N(h)} \sum_{i=1}^{N(h)}\left[X_{i}+h\right)-Z\left(X_{i}\right)\right]^{2}$

Dimana $Z\left(X_{i}\right)$ adalah nilai data di titik $X_{i}, Z\left(X_{i}+h\right)$ adalah nilai data di titik $X_{i}+h$ dan $N(h)$ adalah banyaknya pasangan titik yang memiliki jarak $h$.

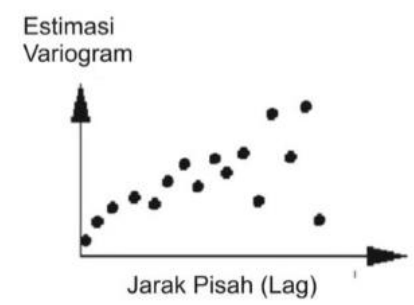

Gambar 3. Grafik variogram eksperimental (Wibowo,2009)

Persamaan ini mendeskripsikan varians antara titik-titik data sebagai sebuah fungsi jarak antara titik-titik data (Lag) h. Perhitungan ini dilakukan untuk setiap jarak lag yang dikehendaki. Jika direpresentasikan dalam bentuk grafik secara umum akan tergambar seperti pada gambar 3. Lag didefinisikan sebagai sebuah rentang jarak yang diberikan oleh jarak minimum dan jarak maksimum. Jumlah titik-titik data dalam sbuah Lag memberikan nilai $\mathrm{N}$ dalam formula diatas. Varians sebuah lag adalah rata-rata varians semua titik data yang terpisahkan oleh lag ini. Variogram eksperimental dihitung untuk arah yang kita definisikan sebelumnya. Arah dari perhitungan variogram sangat menentukan sifat isotropi dan anisotropi data.

\section{b) Variogram teoritis}

Untuk keperluan analisis, variogram experimental ini harus diganti dengan variogram teoritis, yang kurvanya paling mendekati variogram eksperimentalnya. Dalam geostatistik, pencocokan 
antara variogram experimental dan teoritis disebut analisis struktur (structural analysis).

\section{Kriging}

Secara garis besar Kriging dapat dibagi menjadi dua bagian besar, yaitu Linear Kriging dan Nonlinear Kriging. Linear Kriging mengacu pada teknik Kriging yang didasarkan pada asumsi bahwa nilai variabel pada suatu titik memiliki hubungan korelasi spasial secara linear dengan titik-titik yang ada di dekatnya. Nonlinear Kriging sebenarnya merupakan estimasi linear, namun dilakukan pada variabel yang telah ditransformasikan secara noinear menjadi suatu variabel baru, oleh sebab itu dinamakan Nonlinear Kriging. Linear Kriging terbagi menjadi empat metode, yaitu:

1. Simple Kriging Simple Kriging adalah prosedur estimasi Kriging yang paling simpel diantara yang lain. Prosedur ini memerlukan mean populasi, yang sangat mungkin tidak tersedia pada praktek di lapangan tanpa pra-asumsi. Karena itu, prosedur Simple Kriging ini tidak terlalu populer.

2. Ordinary Kriging Ordinary Kriging adalah prosedur Kriging yang paling populer. Prosedur ini mengeliminasi kebutuhan untuk mengetahui mean populasi. Prosedur ini juga lebih mudah mengadaptasi variasi lokal. Prosedur ini adalah prosedur Kriging yang paling banyak diaplikasikan.

3. Co-Kriging Jika kita ingin mengestimasi nilai suatu variabel tertentu dengan menggunakan variabel lainyang tersedia di sekitar lokasi titik itu, maka prosedur Co-Kriging dapat mengakomodasi hal ini. Misalnya, dengan data permeabilitas kita dapat mengestimasi nilai porositas di suatu titik.

\section{Batuan Karbonat}

Batuan karbonat adalah batuan dengan kandungan material karbonat lebih dari $50 \%$ yang tersusun atas partikelkarbonat klastik yang tersemenkan atau karbonat kristalin hasil presipitasi langsung. Bates \&Jackson mendefinisikan batuan karbonat sebagai batuan yang komponen utamanya adalah mineral karbonatdengan berat keseluruhan lebih dari $50 \%$. Sedangkan batu gamping menurut definisi Reijers \&Hsu adalah batuan yang mengandung kalsium karbonat hingga $95 \%$. Sehingga tidak semua batuan karbonat adalahbatugamping. Sementara itu, komponen penyusun batugamping dibedakan atas nonskeletal grain, skeletal grain, matrix dan semen.

\section{N-Standard Penetration Test}

Uji SPT (Standard penetration test) adalah uji yang dilakukan dengan cara pengeboran untuk mengetahui baik perlawanan dinamik tanah maupun pengambilan contoh terganggu dengan teknik penumbukan. Uji SPT terdiriatas uji pemukulan tabung belah dinding tebal ke dalam tanah dan disertai pengukuran jumlah pukulan untuk memasukkan tabung belah sedalam $300 \mathrm{~mm}(1 \mathrm{ft})$ vertikal. Dengan referensi di atas, dapat ditentukan jenis tanah mana yang dapat direkomendasikan untuk dapat dijadikan tanah dasar atau pondasi dari bangunan teknik yang akan dibangun. Oleh karena itu rekomendasi lokasi yang memiliki lapisan tanah yang layak untuk dibangun property di atasnya sangat penting. Secara spesifik dapat dilihat pada tabel di atas, jenis tanah dengan butiran pasir atau lebih kasar, merupakan tanah yang cocok untuk dijadikan tanah dasar atau pondasi.

\section{METODOLOGI}

Pada penelitian ini digunakan data pengukuran geolistrik pada Kabupaten Tuban lebih tepatnya pada Kecamatan Jenu. Dengan jumlah lintasan sebanyak 43 line,panjang lintasan 705 m,jumlah elektroda 48,dan spasi elektroda $15 \mathrm{~m}$ serta konfigurasi yang digunakan adalah konfigurasi wenner. lokasi penelitian dan desain akusisi dapat dilihat pada gambar 4. 


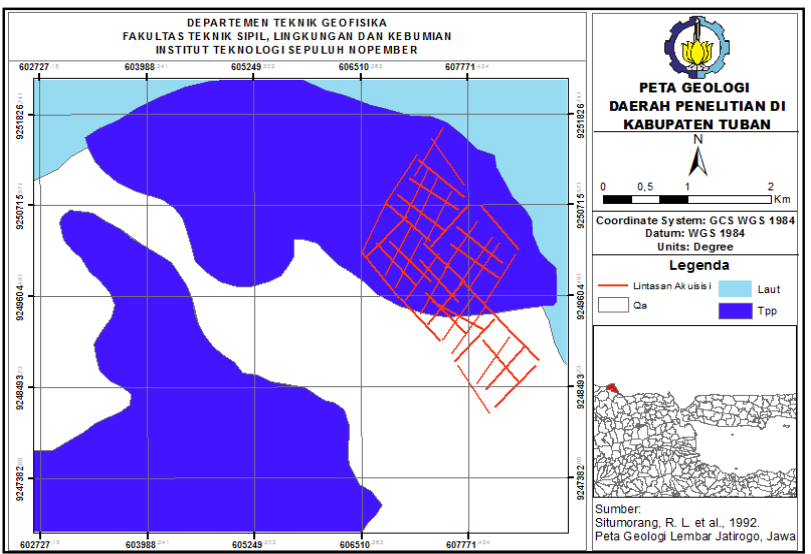

Gambar 4. Gambar desain akuisisi daerah penelitian

Setelah diperoleh data, dilakukan proses pengolahan data yang meliputi beberapa tahapan dari awal studi literatur hingga mendapatkan hasil yang diharapkan. Tahapan-tahapan tersebut dapat digambarkan dalam bentuk diagram alir sebagaimana ditunjukkan pada gambar 5 dibawah ini

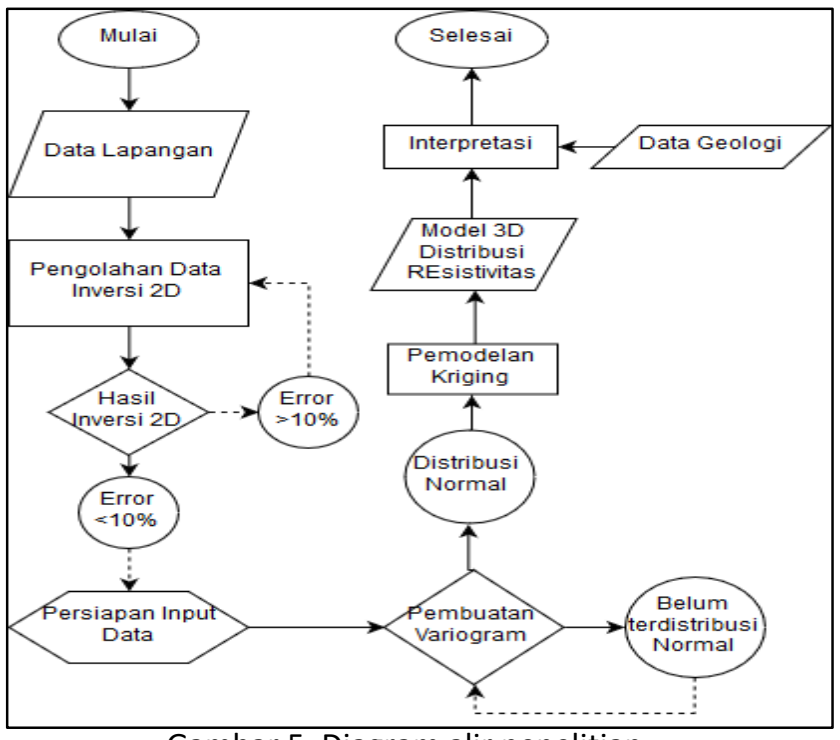

Gambar 5. Diagram alir penelitian

\section{Analisa Hasil Inversi 2D}

Berdasarkan hasil inversi yang kemudian di korelasikan dengan data geologi. Data geologi yang digunakan merupakan informasi peta geologi daerah penelitian yang merupakan formasi paciran dan alluvial. Pada lintasan 6 dan 9 ini menghasilkan 4 macam dugaan litologi dengan total kedalaman $120 \mathrm{~m}$. Berikut merupakan tabel interpretasi hasil inversi 2D.
Tabel 1. Interpretasi litologi batuan dengan nilai range resistivitas

\begin{tabular}{llll}
\hline No & $\begin{array}{l}\text { Range } \\
\text { Resistivitas } \\
\text { (Ohm-m) }\end{array}$ & Warna & $\begin{array}{c}\text { Dugaan } \\
\text { Litologi }\end{array}$ \\
\hline $\mathbf{1}$ & $>100$ & Merah & Dolomit \\
$\mathbf{2}$ & $75-10$ & $\begin{array}{c}\text { Hijau- } \\
\text { kuning } \\
\text { Biru }\end{array}$ & $\begin{array}{l}\text { Batu } \\
\text { Gamping } \\
\text { Butu Pasir }\end{array}$ \\
$\mathbf{3}$ & $3.2-1$ & $\begin{array}{c}\text { Muda } \\
\text { Biru tua- } \\
\text { ungu }\end{array}$ & Batu \\
4 & $<0.32$ & Lempung \\
\hline
\end{tabular}

Terletak paling atas pada tabel 1 , pada kedalaman 0 sampai 25 meter terdapat nilai resistivitas yang paling tinggi yakni 100 sampai $>320$ ohm m diinterpretasikan sebagai dolomit dan terdapat batu gamping disekeliling dolomit. Kemudian pada kedalaman 25 sampai 50 meter terdapat kombinasi yakni sebelah kanan dapat diinterpretasikan sebagai susunan dari dolomit dan batu gamping kemudian dari meter 0 sampai 75 meter (horizontal) dapat diinterpretasikan sebagai batu pasir. Sementara itu, untuk kedalaman lebih dari 50 meter dapat diinterpretasikan sebagian besar merupakan batu pasir yang terdapat sisipan sisipan batu gamping dan batu lempung.

\section{Analisa Variogram}

Analisis variogram merupakan satu tahapan dalam geostatistik yang mendeskripsikan variasi dalam sebuah parameter sebagai sebuah fungsi jarak pisah. Analisa ini didasarkan pada suatu prinsip bahwa dua titik yang berdekatan akan lebih memiliki kemungkinan untuk mempunyai nilai parameter yang mirip dibandingkan dengan dua titik yang berjauhan. Arah dari perhitungan variogram sangat menentukan sifat isotropi dan anisotropi data. Untuk variogram spherical merupakan jenis variogram yang umum untuk digunakan karena merupakan pengaturan umum untuk beberapa metode geostatistik. Pada penelitian ini digunakan variogram spherical. Tipe tersebut juga digunakan untuk simulasi beberapa variasi jumlah lintasan yang lain yakni 21 lintasan dan 11 lintasan. Setelah itu properti resistivitas yang telah dianalisis kemudian dilakukan simulasi kemudian menghasilkan model volumetric 3D. 


\section{Korelasi Dengan N-SPT}

Nilai resistivitas yang dikaitkan dengan litologi batuan dapat diartikan luas. Artinya adalah sifat resistivitas batuan berbentuk jangkauan dan memiliki nilai yang tidak spesifik. Hal tersebut dikarenakan pada tiap batuan memiliki sifat fisis yang berbeda akibat proses geologi. Sehingga pendukung data geologi dan juga korelasi dengan $\mathrm{N}$ SPT menjadi sangat penting dalam proses interpretasi ini. Oleh sebab itu, diperlukan korelasi model 3 dimensi dengan N-SPT sebagai validasi rentang nilai pada model yang telah dibuat. Selain itu, korelasi antara sayatan 2D pada volumetrik hasil geostatistik dan N-SPT dapat menjadi validasi.

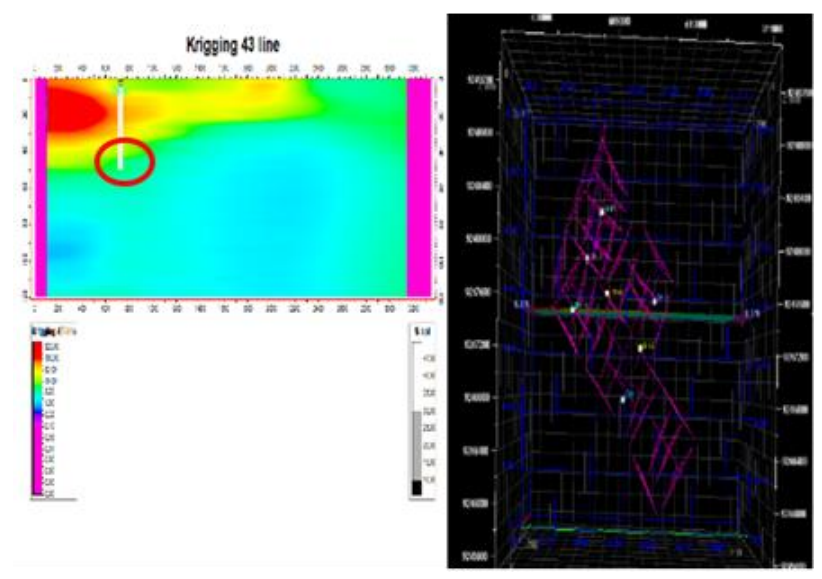

Gambar 6. Korelasi SPT (BH 6) dengan section 43 lintasan

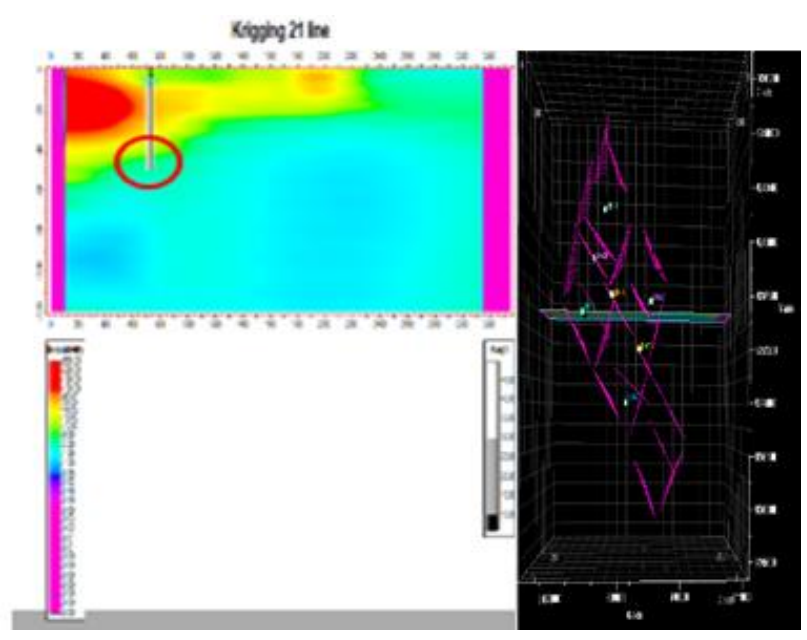

Gambar 7. Korelasi SPT (BH 6) dengan section 21 lintasan

Pada SPT BH-6 nilai resistivitas hasil pemodelan secara statistic dengan menggunakan metode krigging menunjukan pola yang sama yaitu memiliki resistivitas tinggi dan pada zona dengan nilai $\mathrm{N}$ rendah memiliki resistivitas yang relative lebih tinggi dibandingkan resistivitas disekitarnya hal ini menunjukan bahwa zona tersebut dapat diasumsikan sebagai zona batuan karbonat yang memiliki rongga udara dikarenakan resistivitas udara lebih tinggi dibandingkan dengan karbonat.

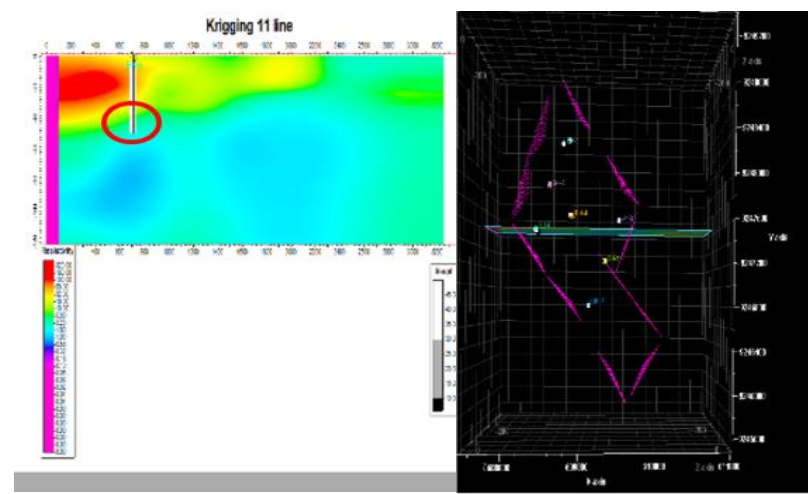

Gambar 8. Korelasi SPT (BH 6) dengan section 11 lintasan

Dapat dilihat dari ketiga gambar diatas, terdapat variasi jumlah lintasan yang dilakukan pada data resistivitas daerah penelitian. Variasi pertama yakni dengan jumlah lintasan 43, kemudian 21 lintasan dan yang terakhir 11 lintasan. Pada gambar 6 dan 7 dengan variasi lintasan 43 dan 21 hasil korelasi spasial terdapat sedikit perbedaan.

Dengan membandingkan titik spt $\mathrm{BH}-6$ maka dapat dilihat bahwa metode SGS dapat lebih baik dalam melakukan pemodelan 3D. Dan model 3D dengan jumlah line 21 (gambar 6) pun masih dapat dipertimbangkan dan dapat dipercaya karena tidak memiliki perbedaan yang signifikan dengan model 43 lintasan (gambar 7), akan tetapi model dengan jumlah line 11 ( gambar 8 ) memiliki perbedaan yang signifikan dengan model 21 lintasan dan model 43 line sehingga hal ini menyebabkan model 11 lintasan memiliki ketidakpastian yang relative lebih tinggi dibandingkan model 43 lintasan dan model 21 lintasan. 


\section{REKONSTRUKSI GEOLOGI}

Berdasarkan interpretasi hasil inversi 2D bahwa nilai resistivitas tinggi merupakan batuan karbonat yakni kombinasi antara batu gamping dan dolomit. Setelah dilakukan proses pemodelan 3D berdasarkan nilai resistivitas, hal yang kemudian dilakukan adalah dengan mengeliminasi nilai kecil dari model tersebut sehingga terbentuk model nilai resistivitas tinggi 3 dimensi. Berdasarkan model 3D yang dihasilkan dan juga analisa geologi yang telah terkorelasi maka dapat diinterpretasikan bahwasanya daerah penelitian tersebut memiliki bentukan persebaran karbonat seperti gambar 12(a).

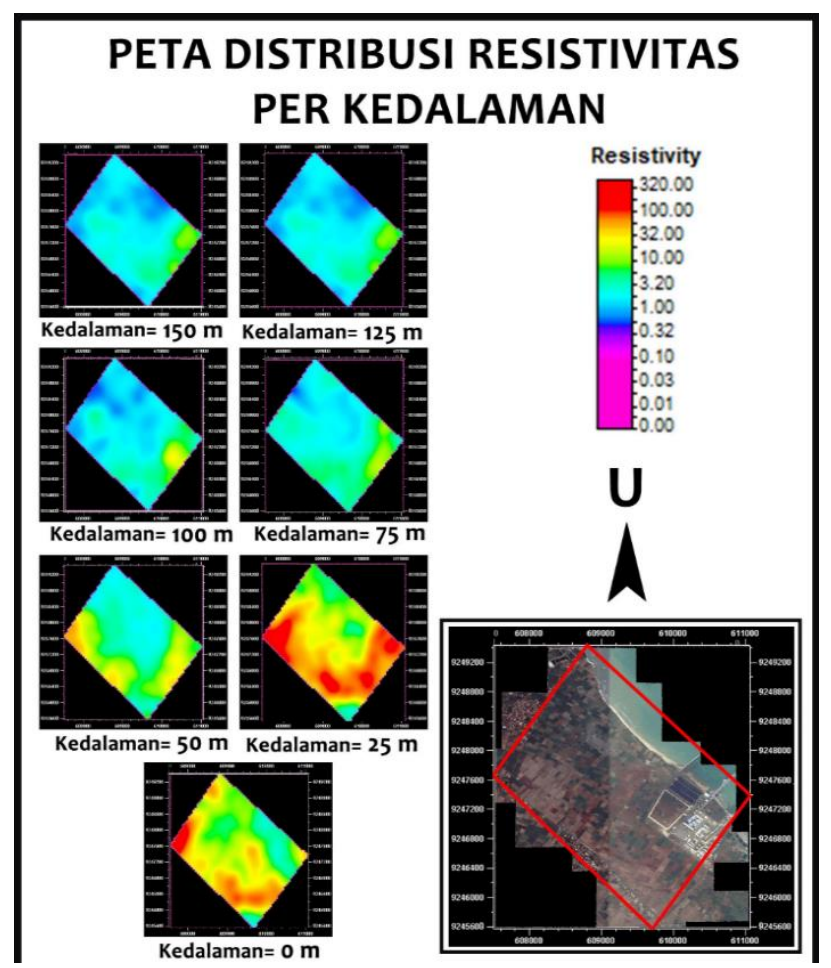

Gambar 9. Peta distribusi resistivitas per kedalaman

Gambar 9 memperlihatkan bahwa terdapat perbedaan persebaran nilai resistivitas tinggi yang diduga sebagai batuan karbonat. Range warna merah merupakan range nilai dolomit, dimana berdasarkan gambar 9 menunukkan bahwa tidak setiap kedalaman terdapat batuan tersebut. Begitu pula dengan range nilai resistivitas yang berwarna kuning yang dapat diiterpretasi sebagai batuan gamping juga menunjukkan pertumbuhan ke permukaan. Menurut gambar 9 Batuan karbonat tumbuh kepermukaan dengan arah utara (arah menuju pantai). Kemudian semakin keatas batu gamping mengalami proses dolomitisasi sehingga semakin keatas batuan karbonat yang mendominasi adalah dolomit.

\section{PENUTUP}

\section{Simpulan}

Dari penelitian yang telah dilakukan di 43 titik pengukuran Geolistrik di Tuban dapat disimpulkan bahwa Model persebaran karbonat mengindikasikan bahwa lingkungan penelitian ini memiliki jenis karbonat reefal.

\section{DAFTAR PUSTAKA}

Al Majid, D. dan Muljo, B. (2017), Pemetaan Potensi Batuan Kapur Menggunakan Citra Satelit Landsat 8 di Kabupaten Tuban, Vol.6, No.2, hal. 1-5.

Guo, E.Y., Chawla, N., Jing, T., Torquato, S. dan Jiao, Y. (2014), "Accurate modeling and reconstruction of three-dimensional percolating filamentary microstructures from two-dimensional micrographs via dilation-erosion method", Materials Characterization, Vol.89, hal. 33-42. http://doi.org/10.1016/j.matchar.2013.12.01.

Hartono dan Suharsono (1997), Peta geologi lembar Tuban, Jawa Timur Pusat Penelitian dan Perkembangan Geologi, Bandung.

Rutley, D.W. (2001), "Quantitative seismic reservoir characterisation: A model-based approach for the Sampang PSC, East Java, Indonesia", Exploration Geophysics, Vol.32, No.4, hal. 275-278. http://doi.org/10.1071/EG01275.

Ward, S.H. (1990), "Resistivity and Induced Polarization Methods", SEG Investigation on Geophysics \#5 Geotecnical and Enviromental, Eds.: SEG, SEG Investigation on Geophysics \#5 Geotecnical and Enviromental, http://doi.org/147. DCIP:2.1.

Wibowo, H. (2009), "MODEL BAWAH PERMUKAAN BERDASARKAN DATA GEOLISTRIK DAN BOR ; STUDI KASUS PENELITIAN Untuk, Lapangan Pltu, Pembangunan Paiton, D I", itb,. 